\title{
Yields of European perch from Upper Lake Constance from 1910 to present
}

\author{
R. ECKMANN \\ Limnological Institute, University of Konstanz, Konstanz, Germany
}

\author{
S. GERSTER \\ Wildlife and Fishery Administration of the Canton of Solothurn, Solothurn, Switzerland
}

\author{
A. KRAEMER \\ Wildlife and Fishery Administration of the Canton of Thurgau, Frauenfeld, Switzerland
}

\begin{abstract}
Commercial yields of perch, Perca fluviatilis (L.), from Upper Lake Constance changed markedly during the 20th century. The perch boom in the 1950s and 1960s is attributed to higher fishing intensity and lake eutrophication. Decreasing yields in recent decades are mainly because of slower growth of perch, while a gradual decrease in year-class strength, and an overall reduction of fishing intensity, might also have contributed to yield reduction. Slower growth is mainly attributed to lake re-oligotrophication and infestation of perch with the pike tapeworm Triaenophorus nodulosus (Pallas). Competition for food with non-native ruffe, Gymnocephalus cernua (L.) is likely of minor importance, while the invasion of the lake by alien macrozoobenthos species has the potential to reduce the food supply for benthivorous perch. Perch yields are assumed to remain at the low level attained at the beginning of the 21 st century; however, under changing climate conditions, fluctuations around the long-term mean will probably be wider than in the past.
\end{abstract}

KEYWORDS: diet, eutrophication, ruffe, Triaenophorus nodulosus, year-class strength.

\section{Introduction}

Anthropogenic eutrophication of freshwater ecosystems during the second half of the 20th century had profound effects on fish communities, particularly in naturally oligotrophic lakes (Zick, Gassner, Filzmoser, Wanzenböck, Pamminger-Lahnsteiner \& Tischler 2006). Increased nutrient loading enhanced productivity, leading in many cases to profound changes of lake biocoenoses and food web structures. When the negative effects of eutrophication on water quality became apparent during the 1960s and 1970s, a series of counter-measures were taken for most European prealpine lakes. These included a ban on P-containing detergents, the collection of sewage effluent (Jeppesen, Sondergaard, Jensen, Havens, Anneville, Carvalho,
Coveney, Deneke, Dokulil, Foy, Gerdeaux, Hampton, Hilt, Kangur, Köhler, Lammens, Lauridsen, Manca, Miracle, Moss, Nöges, Persson, Phillips, Portielje, Romo, Schelske, Straile, Tatrai, Willén \& Winder 2005a) and its processing in treatment plants with chemical phosphorous stripping, and the reduction of agricultural fertiliser use in the catchments. These measures started to take effect in the 1980s and lake eutrophication was reversed within about two decades, a process termed re-oligotrophication. By the beginning of the 21 st century phosphorus concentrations are approaching, or have already returned to, pre-eutrophication levels (Jeppesen et al. 2005a).

The effects of eutrophication on fish populations were studied predominantly in salmonid species, particularly coregonids/whitefish (genus Coregonus)

Correspondence: Dr Reiner Eckmann, Limnological Institute, University of Konstanz, D-78457 Konstanz, Germany (e-mail: reiner.eckmann@uni-konstanz.de)

Present address: A. Kraemer, Spitzrütistrasse 16, CH-8500 Frauenfeld/TG, Switzerland. 
(Colby, Spangler, Hurley \& McCombie 1972; Nümann 1972; Hartman 1972; Roth \& Geiger 1972), and less intensively in perch, Perca fluviatilis (L.) (Leach, Johnson, Kelso, Hartmann, Nümann \& Entz 1977). The general pattern observed was growth acceleration coupled with higher yields. The effects of re-oligotrophication on fish communities have received less attention so far (Müller \& Bia 1998; Mills, Casselman, Dermott, Fitzsimons, Gal, Holeck, Hoyle, Johannsson, Lantry, Makarewicz, Millard, Munawar, Munawar, O'Gorman, Owens, Rudstam, Schaner \& Stewart 2003; Jeppesen, Jensen, Sondergaard \& Lauridsen 2005b), which might be because of the general relief that in many lakes recovery targets have been met and the negative consequences of eutrophication abated.

During lake re-oligotrophication, however, fish biocoenoses, food web interactions and yields will not simply return to the pre-eutrophication situation (cf. Mills et al. 2003), as a wide variety of conditions have changed in the meantime. Fishing gears are more efficient today because of the advent of nylon gill nets in the 1950s. Phyto- and zooplankton species compositions have changed, and these changes cannot simply be reversed, e.g. in those lakes where certain species have become extinct during eutrophication. Alien invasive species, particularly fish species, have colonised many lakes, and climate conditions may affect fish communities differently today. Therefore, it is important to study fish communities and to monitor fishery yields in lakes that are undergoing re-oligotrophication.

Fish species will react differently to re-oligotrophication, depending on where along a productivity gradient they thrive best. Coregonids, which dominate in oligotrophic lakes, should generally benefit from reoligotrophication. European perch on the other hand are most abundant in mesotrophic lakes (Colby et al. 1972; Hartmann 1977; Persson, Diehl, Johansson, Andersson \& Hamrin 1991), suggesting that perch will be at a disadvantage in formerly eutrophicated lakes that undergo re-oligotrophication. European perch are widely distributed in temperate lakes of Eurasia, and both commercial and recreational fishers target them. Any major changes in perch yields, therefore, attract the immediate attention of fishers and challenge fisheries managers to explore the likely reasons and eventually to take appropriate measures to stabilise yields. For a thorough analysis of fishery yield fluctuations, however, long-term data sets on yields, population dynamics parameters, and general limnology are essential.

This study reviews the fluctuations in perch yield from a large prealpine lake, and analyses how they are influenced by changes of lake trophic state, taking Upper Lake Constance as an example. The lake is particularly suited for this purpose as an uninterrupted record of the commercial fishery harvest is available, which dates back to the beginning of the 20th century. Additionally, the perch stock has been regularly monitored through monthly test fishing since the beginning of the 1970s, and different aspects of perch biology have been studied repeatedly during recent decades. Finally, the general limnology of Lake Constance is well studied, and an uninterrupted record of limnological variables with high temporal resolution is available since the early 1960s.

\section{Materials and methods}

Upper Lake Constance is a large $\left(472 \mathrm{~km}^{2}\right)$, deep $\left(z_{\max }=254 \mathrm{~m}, \quad z_{\text {mean }}=101 \mathrm{~m}\right)$, warm monomictic prealpine lake situated at the northern fringe of the European Alps $\left(9^{\circ} 18^{\prime} \mathrm{E}, 47^{\circ} 39^{\prime} \mathrm{N}\right)$ (Fig. 1). The lake is shared by Austria, Germany and Switzerland. Lake level is not regulated so it fluctuates by about $1.5 \mathrm{~m}$ from low water in late winter to high water in summer. With rare exceptions, the lake does not freeze (the last complete freeze-over was in 1963). The lake was originally oligotrophic but underwent pronounced eutrophication during the 20th century. Total phosphorus concentration during winter mixing in February/March $\left(\mathrm{TP}_{\text {mix }}\right)$ peaked around 1980 at $>80 \mu \mathrm{g} \mathrm{L}^{-1}$ (Bäuerle \& Gaedke 1998). As a result of drastically reduced $\mathrm{P}$ input, the lake returned to oligotrophy by the beginning of the 21st century $\left(\mathrm{TP}_{\text {mix }}\right.$ in 2004 : $9 \mu \mathrm{g} \mathrm{L}^{-1}$ ) (cf. Fig. 2).

Twenty-nine fish species occur in the lake (Eckmann \& Rösch 1998), which is about the same number as 100 years ago (Klunzinger 1892). Of these species, only a few are of commercial interest and exploited intensively: two forms of lake whitefish (an inshore and a pelagic spawning form of Coregonus lavaretus L.), European perch, eel, Anguilla anguilla (L.), which cannot migrate naturally into the lake because of a waterfall downstream of the lake but which is regularly stocked, a migratory form of brown trout, Salmo trutta L., which spawns in lake tributaries, pike, Esox lucius L., Arctic charr, Salvelinus alpinus (L.), and pikeperch, Sander lucioperca (L.). The bycatch of cyprinid species has little commercial value. During recent decades, perch was the second most important species after lake whitefish, both in terms of catch volume and economic importance for the commercial fishery. Two genetically distinct subpopulations of perch coexist in Lake Constance (Gerlach, Schardt, Eckmann \& Meyer 2001; Behrmann-Godel, Gerlach \& Eckmann 2004), 


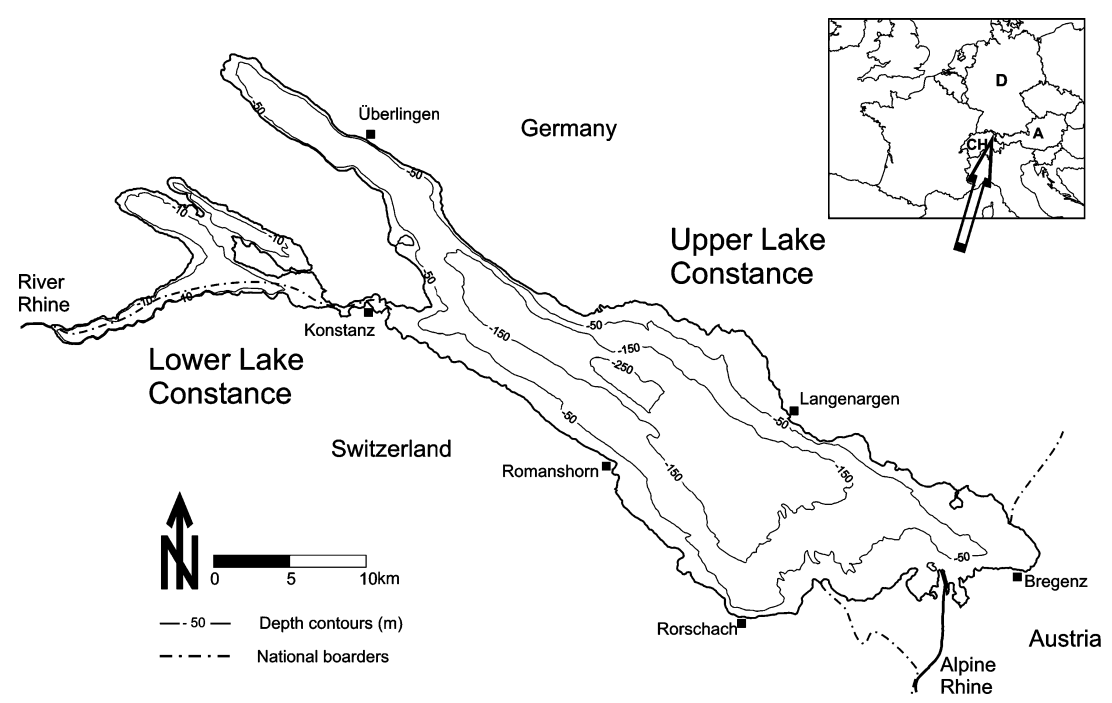

Figure 1. Map of Lake Constance showing the deep upper and the shallow lower basin. Tributaries apart from the Alpine Rhine are not shown. Upper Lake Constance is a condominium of the boardering countries, i.e. no national boarders are defined.

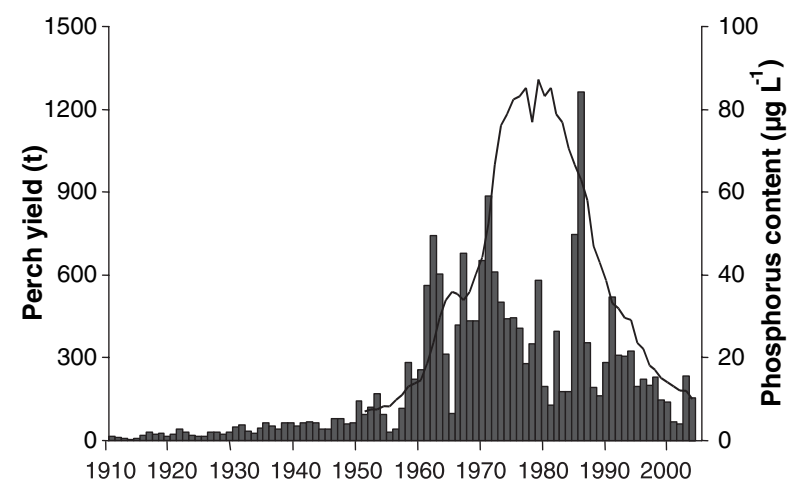

Figure 2. Annual commercial yield of perch from Upper Lake Constance (bars), and volume-weighted average $\mathrm{PO}_{4}-\mathrm{P}$ content during spring mixing (line).

one in Lower and one in Upper Lake Constance. This study refers to yields from the subpopulation in Upper Lake Constance.

Perch is fished with bottom gill nets $(2 \mathrm{~m}$ high, $100 \mathrm{~m}$ long, $28-32 \mathrm{~mm}$ bar mesh, $0.12 \mathrm{~mm}$ yarn diameter). Fishers may use up to six nets, which are set overnight on up to six nights per week. Closed seasons are specified during perch spawning time (1 May-20 May) and around the spawning time of inshore spawning whitefish (15 November-9 January). The bag limit for anglers is 50 perch per day. The commercial fishery is not regulated by harvest quotas but by adjusting fishing intensity, e.g. by reducing the number of nets or fishing days per week, if necessary. These fishing regulations are identical in all bordering countries.
An uninterrupted record of commercial catches from Upper Lake Constance is available since 1910 based on monthly catch reports of all fishers. These reports are made anonymous during compilation, and they are not supplied to revenue authorities to avoid bias towards low yields. Biological data on perch are collected monthly by fishery wardens according to a standardised protocol since the early 1970s (Gerster, Staub \& Krämer 1995). Age is determined from opercular bones. Length-at-age is the mean length of all fish from one year-class sampled with multimesh gill nets from October to December, i.e. when growth of perch has ceased. Sex, maturity stage and infection with pike tapeworm, Triaenophorus nodulosus (Pallas), are assessed after dissection. Stomach contents are inspected with the naked eye and classified as perch, non-identified fish, zooplankton and zoobenthos. Estimates of virtual year-class strength (YCS) are obtained from age compositions in the test fishery (considering the legal mesh size only) in combination with monthly yield volumes of the commercial fishery. All data collected are summarised in annual reports to the International Commission for the Fisheries Management of Upper Lake Constance (IBKF).

\section{Results}

\section{Commercial yields}

During the first half of the 20th century, perch yields were low. They increased in the 1950s and decreased again during the 1990s (Fig. 2). In the four decades 
from 1910 to 1950, perch decadal yields averaged (mean \pm S.D.) $17 \pm 8.7,25 \pm 8.0,50 \pm 12.5$, and $61 \pm 13.2 \mathrm{t}$ respectively. The sharp increase of yields during the 1950s (decadal mean: $132 \pm 77 \mathrm{t}$ ) was followed by three decades with high and highly variable yields $(454 \pm 199, \quad 516 \pm 175, \quad$ and $379 \pm 362 \mathrm{t}$ respectively). The remarkably high yields in 1985 and 1986 were almost entirely because of an extraordinarily strong 1982 cohort. Yields decreased during the 1990s (274 $\pm 104 \mathrm{t})$, falling to below $100 \mathrm{t}$ (for the first time since 1965) in 2001 and 2002. As the catches of coregonids changed less than those of perch during the second half of the 20th century, the contribution of perch to the total catch increased markedly in the 1960 s to around $50 \%$ and decreased again in the 1990 s to less than $20 \%$. Perch yield was significantly related to $\mathrm{TP}_{\text {mix }}$ (Spearman's $\rho=0.524$, $P<0.001$ ), but there are discrepancies (Fig. 2), e.g. low yields during the years when $\mathrm{TP}_{\text {mix }}$ peaked, and the generally lower yields during re-oligotrophication.

\section{Growth rate}

Total length at the end of the growing season of the age-classes 0,1 and 2 decreased during the last two decades, most notably during the late 1990s/early 2000s (Fig. 3). These three age-classes are on average 1,2 and $5 \mathrm{~cm}$ smaller today than nearly 20 years ago. Using a generalised length-weight regression for perch from Upper Lake Constance, these reductions in size translate into reductions in mass of 2, 12 and $59 \mathrm{~g}$ for the three age-classes respectively. As females grow faster than males, the former are on average 6 months younger at a given length than the latter.

There are no data of comparable quality and temporal coverage available on the growth of perch

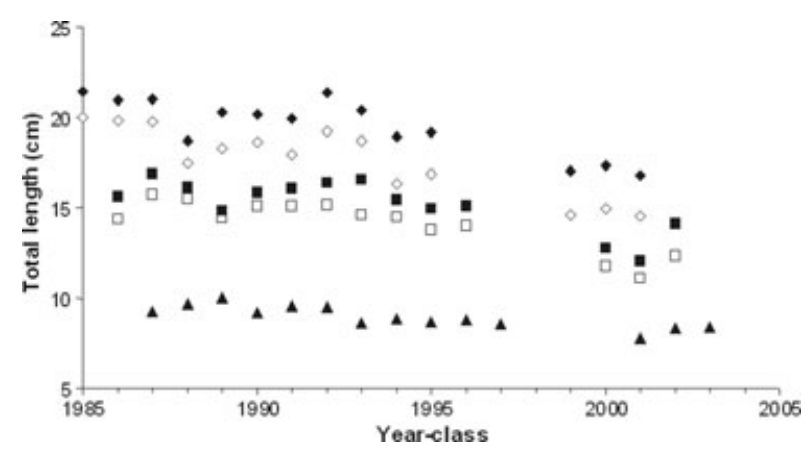

Figure 3. Perch total length at the end of the growing season, based on fish caught with multimesh gill nets from October to December. For age-0 perch both sexes are combined. No samples were taken from 1998

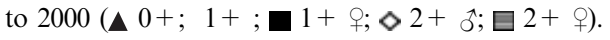

in Lake Constance prior to and during eutrophication. Hartmann (1975) back-calculated growth of the cohorts of 1967-1971 and compared his results with an early study by Haakh (1929). During the first 3 years of life, perch grew much better in the 1970s than in the 1920s, attaining up to $5 \mathrm{~cm}$ greater total length. The length of female perch at the end of their second year of life ranged from about 14.5 to $18 \mathrm{~cm}$ in the early 1970s, which is similar to the values observed during the late 1980s/early 1990s (Fig. 3).

\section{Diet composition}

Perch diet changed markedly during the 20th century. Prior to lake eutrophication, perch performed an ontogenetic diet shift from zooplankton through zoobenthos to fish. They became piscivorous at about $20 \mathrm{~cm}$ total length and were almost exclusively cannibalistic (Nümann 1939; Amann 1955). During lake eutrophication, zooplankton became the most important food source for perch, replacing zoobenthos and partly even fish (Hartmann 1975). Concurrently, the perch were no longer confined to the littoral zone but also used the open water, where even the largest fish fed exclusively on zooplankton (Becker 1988). At the beginning of the 21 st century, perch feeding habits have almost completely reversed to the pre-eutrophication pattern (IBKF, unpublished report). Zoobenthos, however, still contributes much less to the juvenile perch's diet today (D. Schleuter, personal communication) compared with the 1930s (Nümann 1939), as today they consume zooplankton in addition to zoobenthos. The frequency of cannibalism among perch caught in 28 and $32 \mathrm{~mm}$ gill nets increased from around $5 \%$ in the years $1975-1988$ to between $10 \%$ and $40 \%$ in recent years (Fig. 4). The frequency of occurrence of piscivory (considering perch and unidentified prey fish) increased even more strongly to between $50 \%$ and $85 \%$.

\section{Year-class strength}

Average virtual YCS of perch in Upper Lake Constance has not changed significantly since 1970 (ANOVA, $P>0.05)$. The decadal averages $( \pm \mathrm{SD})$ for the $1970 \mathrm{~s}$, $1980 \mathrm{~s}$ and $1990 \mathrm{~s}$ are $3.1 \pm 2.7,3.6 \pm 5.6$, and $1.6 \pm 0.8$ million individuals respectively. The cohort of 1982 was exceptionally strong with 17.8 million individuals (Fig. 5). Omitting this datum, the value for the 1980s reduces to $2.1 \pm 2$ but the trend for YCS to decline with time is still not significant. Statistical evidence was found by Gerster et al. (1995), using multiple linear regression analysis, for a strong impact 


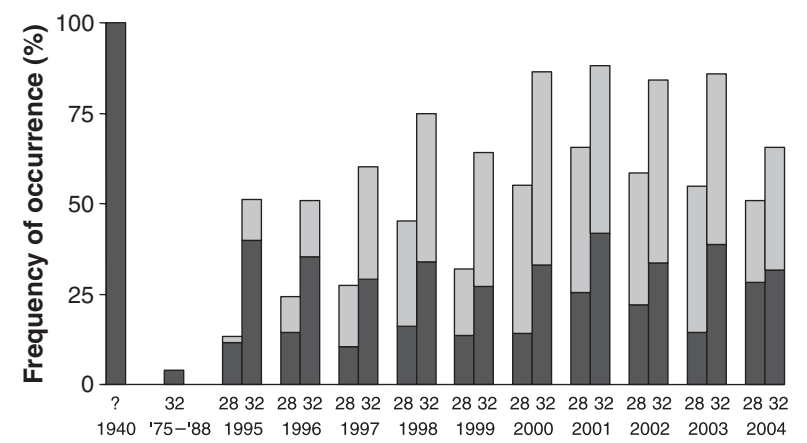

Figure 4. Frequency of occurrence of perch (black bars) and nonidentified fish (grey bars) in stomachs of perch from Upper Lake Constance (yearly averages of all non-empty stomachs) before eutrophication started (1940), under mesotrophic lake conditions (19751988), and during re-oligotrophication (1995-2004). Fish were sampled with either 28 or $32 \mathrm{~mm}$ gill nets (indicated below the bars). Mesh size used in 1940 is unknown. Numbers of full stomachs analysed per mesh size and year range from 83 to 475 . Number of stomachs analysed in 1940 is unknown. About 1800 stomachs were analysed from 1975 to 1988. Data sources: Nümann (1939), Amann (1975), Krämer \& Baroffio (1988), Becker (1988), IBKF (annual reports).

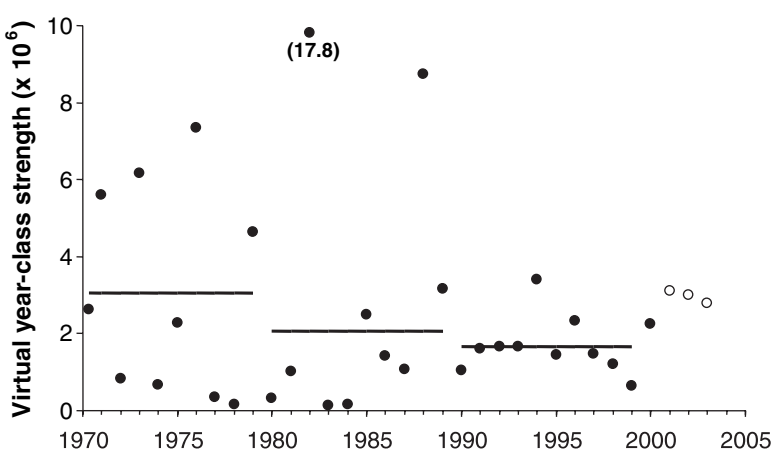

Figure 5. Virtual year-class strength of perch from Upper Lake Constance. Horizontal lines denote decadal means (excluding the outlying year-class 1982). Open circles: preliminary estimates only, as cohorts are not yet fished out.

of cannibalism on perch YCS. Spawning success, defined as YCS divided by the number of female spawners, was significantly related to the number of cannibalistic perch that lived in the lake when a new cohort was born $\left(r^{2}=0.51\right.$ for a second degree polynomial regression on log-transformed values). When the regression of spawning success on number of cannibals is recalculated either for the entire data base that is available today (1972-1999), only for those years with reportedly low incidence of cannibalism (1975-1989), or for the recent years with strongly increasing incidence of cannibalism (1990-1999), the $r^{2}$ differ little (0.51, 0.55 and 0.58 respectively).

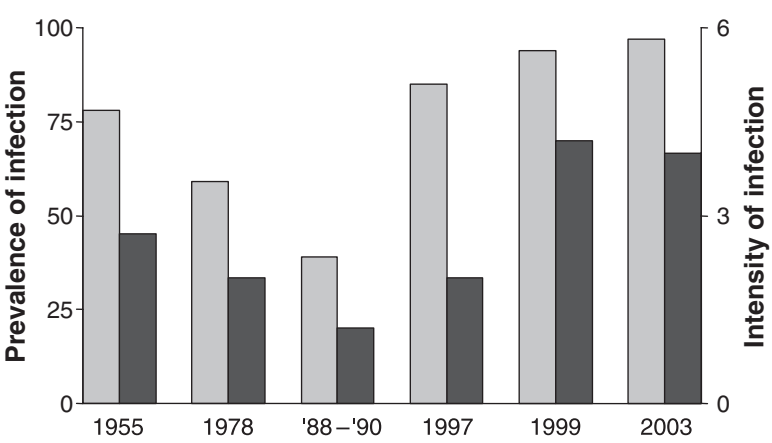

Figure 6. Prevalence (\% of fish infected) (grey bars) and intensity of infection (no. of plerocercoid cysts per fish) (black bars) with pike tapeworm, Triaenophorus nodulosus, among perch from Upper Lake Constance of age-1 and older. Data sources: Amann (1975), Özcelik (1978), Balling (1992), Dieterich \& Eckmann (2000), Brinker (2000) and Brinker \& Hamers (2005).

\section{Infection with pike tapeworm}

Prevalence and intensity of infection with pike tapeworm attained alarmingly high levels (Fig. 6) in Upper Lake Constance perch by the end of the 20th century (Brinker 2000; Dieterich \& Eckmann 2000). Pike tapeworm has a complex life cycle involving two intermediate hosts, a copepod and a zooplanktivorous fish, and northern pike as the final host. When an infected copepod is eaten by, for example, a perch, tapeworm plerocercoids invade the host's liver where they are eventually encysted. The observations of severely damaged perch livers containing up to 50 plerocercoid cysts, plus several free plerocercoids of unusually large size (Brinker \& Hamers 2005), suggested that parasite infection might have a negative influence on perch growth rate. Indeed, statistical analysis showed that length-at-age was inversely related to the intensity of parasite infection (Brinker \& Hamers 2005), whereby this effect seems to be most pronounced for age-2 and older fish.

\section{Discussion}

The increase in perch yields during the 1950s and early 1960s was in part because of higher fishing intensity caused by two major developments. The replacement of cotton gill nets by more efficient monofilament nylon gill nets by the mid-1960s was the most important change to the perch fishery at Upper Lake Constance that occurred during the almost 100 years on record. Additionally, when fishers started to fillet perch during the 1950s, the demand for perch boomed, and fishing intensity increased by a factor of four from 1959 to 1967 (Hartmann \& Nümann 1977). During the perch boom, more than 230 fishers were each licensed 
to fish with 20 bottom gill nets of $32 \mathrm{~mm}$ bar mesh. When yields declined, the number of licenses came down to about 160 by the year 2000, and today each fisher may use only six gill nets of $28-32 \mathrm{~mm}$ bar mesh. Therefore, fishing intensity has dropped to $20 \%$ of its maximum value (without considering mesh size reduction) after the initial increase by a factor of four in the 1960s.

Higher yields were also because of larger fish being caught. Perch growth rate increased with eutrophication, it stayed at a high level during the 1970s and 1980s, and declined again markedly at the end of the 20th century. The recent decrease of perch growth rate is generally attributed to the poorer food supply in oligotrophic Lake Constance. The growth of age-2 females, quantified as the width of the opercular annulus is, however, not correlated with $\mathrm{TP}_{\text {mix }}(P=$ 0.94) for the years 1971 to 1997 . Perch standing stock size on the other hand, which was quantified as the virtual number of perch older than 1 year that are present in the lake at the start of the growing season, is the single most important variable related to age-2 female growth $\left(r^{2}=0.35\right)$. In a multiple linear regression model, the cumulative sum of water temperature that exceeds $14{ }^{\circ} \mathrm{C}$ measured at the lake outlet accounts for another $15 \%$ of female growth variance. When $\mathrm{TP}_{\text {mix }}$ is entered into the model as the third variable, the model's adjusted $r^{2}$ increases to 0.67 (all independent variables are significant at $P<0.01, n=$ 27). This analysis suggests that P-content is not the main factor that influences perch growth but intraspecific competition for food seems to be more important.

The profound changes in the composition of perch diet were most likely caused by the eutrophicationmediated increase of pelagic zooplankton biomass during the 1950s and 1960s, followed by a decline during the 1990s (IGKB 2004). The almost complete lack of cannibalism among large perch during the 1980s (Fig. 4), however, was probably not only caused by the high abundance of zooplankton. Coinciding with the eutrophication, submerged macrophytes boomed, particularly Potamogeton pectinatus L. and Zannichellia palustris L. (IGKB 1998). These dense macrophyte stands provided shelter for juvenile perch, rendering them less available to potential predators (Wang \& Eckmann 1994). During re-oligotrophication the formerly abundant shelters for juvenile perch virtually disappeared, and they are only partly replaced by less densely growing macrophytes that are typical for oligotrophic conditions. Hence, apart from reduced zooplankton abundance the lack of shelter may be another reason for the resurgence of cannibalism during the 1990s.
The result from the statistical analysis of perch YCS, that the number of cannibals accounts for a similar proportion of spawning success variance during all the time periods analysed, contradicts the data on cannibalism among perch, which were derived from regular stomach content analyses (cf. Fig. 4). These data suggest a more pronounced impact of cannibalism on cohort size during recent years than the 1970s and 1980s. The diet of larger perch and their distribution patterns in eutrophic Lake Constance may explain why the statistically significant impact of cannibalism on spawning success was not supported by stomach content analyses. During the 1970s and 1980s, perch consumed zooplankton not only in the littoral but also in the pelagic zone. The larvae's habitat and the feeding grounds of larger perch thus overlapped, providing the possibility for larger perch to prey on larvae. If cannibalism occurred during these years (as suggested by the statistical analysis), it most likely passed undetected, because larvae are rapidly digested and can thus be easily overlooked. In oligotrophic Lake Constance, however, where the pelagic larvae are spatially separated from the littoral dwelling larger perch during their first months of life, cannibalism is directed towards larger young-of-the-year or even age1 fish, which are more likely to be detected in the routine stomach content analyses.

Apart from the poorer food supply in oligotrophic Lake Constance, the recent decrease of perch growth rate is also caused by the massive infection in perch with pike tapeworm. The changes across time of pike tapeworm prevalence and intensity of infection in perch are, however, not related to pike yields. These were above $10 \mathrm{t} \mathrm{yr}^{-1}$ until 1964, they decreased to below $5 \mathrm{t}$ by 1967 and have surpassed this figure only in the last 4 years. When pike yields are taken as a proxy for standing stock size it can be concluded that the size of the pike stock is not directly related to the parasite burden in perch. The lake's trophic state on the other hand seems to be related to pike tapeworm infection of perch. In oligotrophic Lake Constance, the crustacean plankton community was dominated by copepods, while under mesotrophic conditions the relative contribution of cladocerans to the total crustacean biomass increased. Recently, total zooplankton abundance has declined notably, and additionally, copepods have started to dominate again (IGKB 2004). Copepods but not cladocerans are the first intermediate hosts of $T$. nodulosus. Therefore, with lower overall zooplankton biomass and increasing relative abundance of copepods, the probability that perch will ingest infected copepods, and hence infection risk is higher (Brinker \& Hamers 2005). 
In addition to the generally poorer food supply during re-oligotrophication, competition for zoobenthos with non-native ruffe, Gymnocephalus cernua (L.), may influence perch growth rate. Ruffe became established in Lake Constance in the 1980s. A few years later, it became one of the most abundant species in the littoral zone (Rösch \& Schmid 1996). Ruffe, being the superior competitor for macrozoobenthos (Bergman 1991; Bergman \& Greenberg 1994), might delay or even impede the diet switch of juvenile perch from zooplankton to zoobenthos. Comparative studies on the competitive abilities of perch and ruffe in Lake Constance (Dieterich, Baumgärtner \& Eckmann 2004a; Dieterich, Mörtl \& Eckmann 2004b; Schleuter \& Eckmann 2005) and in other lakes that had been colonised by ruffe at roughly the same time as Lake Constance (Savino \& Kolar 1996; Fullerton, Lamberti, Lodge \& Berg 1998; Fullerton, Lamberti, Lodge \& Goetz 2000) basically agreed that newly established ruffe populations have the potential to affect native perch or yellow perch populations negatively.

Reliable predictions of the future development of ruffe and perch populations in large and deep lakes, however, have not been obtained. This is because of the limited knowledge of the species' habitat choice in large and deep lakes, where the concepts developed in shallow northern European lakes, where perch and ruffe segregate into different depth strata (Bergman 1991), do not apply. While ruffe stay at depths of 10 $20 \mathrm{~m}$ during the day in Lake Constance, where they consume only a little food, they move into the shallow littoral zone to feed at night (D. Schleuter, personal communication), i.e. their main foraging macro-habitat is the same as for benthivorous perch.

The two species, however, may differ in microhabitat use. Laboratory feeding experiments suggested that exploitative competition might not be strong, being alleviated by the species' divergent food and substrate preferences (Dieterich et al. 2004a, b). On the other hand, ruffe was found to be more aggressive than perch, gaining access to a benthic food source more often and for a longer time than perch (Schleuter \& Eckmann 2005). Nevertheless, it was suggested that interference competition might not be important for the species' interactions because of their different activity patterns, perch being active during daylight and ruffe mainly at night.

As the ruffe's relative abundance within a fish community is highest under eutrophic conditions (Persson et al. 1991), the boom of ruffe in Lake Constance during the ongoing re-oligotrophication in the $1980 \mathrm{~s} / 1990$ s is surprising. Newly established species are, however, notorious for a boom and bust cycle after colonising a new habitat. While ruffe was similarly, or even more abundant than perch during the late 1990s, its abundance has decreased notably in recent years (Reyjol, Fischer, Lek, Rösch \& Eckmann 2005). It is expected that ruffe will continue to dwell in Lake Constance even under oligotrophic conditions, but that its abundance will remain low or decrease further. At lower ruffe density, competition with perch will probably be of minor importance, and perch growth and yields will not be strongly affected by ruffe.

The benthic food supply for perch may also be affected by alien aquatic species. Several aquatic invasive macrozoobenthos species have colonised Lake Constance recently, e.g. Corbicula fluminea (Müller), a freshwater clam, and the amphipod Dikerogammarus villosus (Sovinsky) (LfU 2005). As many other alien macrozoobenthos species are already present in the River Rhine downstream of Lake Constance, it is probably only a question of time until at least some of them will make their way into the lake. Among the new invaders, $D$. villosus has probably the greatest potential to modify and/or to reduce the benthic food supply for perch. D. villosus is a potent predator preying voraciously on other gammarids (Dick \& Platvoet 2000; Kinzler \& Maier 2003). Although D. villosus was almost immediately included into the diet of perch, ruffe and burbot, Lota lota (L.), the introduction of a new carnivorous species into the benthic food web will lower the trophic transfer efficiency. This effect is particularly relevant under oligotrophic conditions, where perch rely to a great extent on macrozoobenthos prey whose biomass will decline with the ongoing reoligotrophication. Invasive macrozoobenthos species thus have the potential not only to change the native community structure and function but to affect the top consumers by reducing their food supply, which will eventually translate into lower fishing yields.

Extreme weather conditions are predicted to occur more frequently in the Lake Constance region in the future (BayFORKLIM 1999). The summer of 2003, for example, was the warmest on record since 1870 (German Meteorological Service). High epilimnetic temperature promoted a high survival rate of the 2003 perch cohort during the first weeks of life. The high density of young-of-the-year perch facilitated cannibalism, not only among adults but also among juvenile perch. As a consequence, growth rates of (cannibalistic) perch increased markedly, resulting in a commercial yield of $231 \mathrm{t}$ (cf. Fig. 2), which is about three times more than in the previous year. With increasing frequency of extreme weather conditions, perch yields are expected to fluctuate 
more widely and more erratically than they used to under similar trophic conditions more than half a century ago.

It is concluded that changes in fishing pressure and in lake trophic state - the latter affecting perch growth rate in a variety of ways - had the strongest impact on perch yields during the last five decades. It is expected that perch yields from oligotrophic Upper Lake Constance will stay at the level attained at the beginning of the 21st century for the foreseeable future. However, because of the invasion of the lake by alien macrozoobenthos species, yields might decline even further. Because the restructuring of the benthic food web is already under way, and extreme weather conditions seem to be on the rise, any predictions of perch growth, population dynamics and yields become increasingly uncertain.

\section{Acknowledgments}

We are indebted to the Swiss fishery wardens Hermann Traber at Romanshorn, Hanspeter Ribi at Ermatingen, and Markus Zellweger at Romanshorn who collected data from more than 32000 perch, and to Hanspeter Ribi who performed all age determinations. Without their commitment this study would have never been possible. Additional data were provided by personnel of the Institut für Seenforschung and of the Fischereiforschungsstelle, both at Langenargen. The comments by two anonymous reviewers helped to improve an earlier version of this manuscript. This study was partly supported by Deutsche Forschungsgemeinschaft within the collaborative research center SFB 454, Littoral of Lake Constance. M. Morris corrected the English in an earlier version of the manuscript.

\section{References}

Amann F. (1955) Der Befall der Bodenseefische mit Triaenophorus unter besonderer Berücksichtigung des biologischen Cyclus, Dissertation. Germany: University München. (in German).

Amann F. (1975) Nahrungsumstellung und Zunahme der Barsche (Perca fluviatilis) im Bodensee-Obersee infolge der Eutrophierung. Österreichs Fischerei 28, 72-76 (in German).

Balling T. (1992) Saisonale und standortabhängige Verbreitung von Fischparasiten im Bodensee-Obersee und ihr Einfluss auf den Ernährungszustand der Fische, $\mathrm{PhD}$ thesis.Germany: University Tübingen, 132pp. (in German).

Bäuerle E. \& Gaedke U. (eds) (1998) Lake Constance, characterization of an ecosystem in transition. Archiv für
Hydrobiologie, Special Issues Advances in Limnology 53, 610pp.

Bayerischer Klimaforschungsverbund (BayFORKLIM) (1999) Klimä̈nderung in Bayern und ihre Auswirkungen. München: Abschlußbericht. Bayerischer Klimaforschungsverbund, 90pp (in German).

Becker M. (1988) Freilandökologische Untersuchungen an planktivoren Fischen des Überlinger Sees mit Schwerpunkt einer differenzierten Nahrungsanalyse. Diploma thesis, Germany: University Konstanz, 112pp. (in German).

Behrmann-Godel J., Gerlach G. \& Eckmann R. (2004) Postglacial colonization shows evidence for sympatric population splitting of Eurasian perch (Perca fluviatilis L.) in Lake Constance. Molecular Ecology 13, 491-497.

Bergman E. (1991) Changes in abundance of two percids, Perca fluviatilis and Gymnocephalus cernua, along a productivity gradient: relations to feeding strategies and competitive abilities. Canadian Journal of Fisheries and Aquatic Sciences 48, 536-545.

Bergman E. \& Greenberg L.A. (1994) Competition between a planktivore, a benthivore, and a species with ontogentic diet shifts. Ecology 75, 1233-1245.

Brinker A. (2000) Der Befall des Flußbarsches (Perca fluviatilis L.) im Bodensee mit dem Hechtbandwurm (Triaenophorus nodulosus P.). Diploma Thesis, Germany: University Freiburg/Br., 106pp. (in German).

Brinker A. \& Hamers R. (2005) Untersuchungen zur Parasitierung der Barsche mit dem Hechtbandwurm. BAFU, Bern (CH), Mitt. zur Fischerei 78, 35-45 (Download PDF available at: http://www.umwelt-schweiz.ch/buwal/shop/ files/pdf/phppJkyx.pdf. Code: MFI-78-D) (in German).

Colby P.J., Spangler G.R., Hurley D.A. \& McCombie A.M. (1972) Effects of eutrophication on salmonid communities in oligotrophic lakes. Journal of the Fisheries Research Board of Canada 29, 975-983.

Dick J.T.A. \& Platvoet D. (2000) Invading predatory crustacean Dikerogammarus villosus eliminates both native and exotic species. Proceedings of the Royal Society of London B 267, 977-983.

Dieterich A. \& Eckmann R. (2000) The infection of Eurasian perch Perca fluviatilis L. with Triaenophorus nodulosus (Pallas) plerocercoids in Lake Constance (Germany). Bulletin of the European Association of Fish Pathologists 20, 34-39.

Dieterich D., Baumgärtner D. \& Eckmann R. (2004a) Competition for food between Eurasian perch (Perca fluviatilisL.) and ruffe (Gymnocephalus cernuus [L.]) over different substrate types. Ecology of Freshwater Fish 13, 236-244.

Dieterich A., Mörtl M. \& Eckmann R. (2004b) The effects of zebra mussels (Dreissena polymorpha) on the foraging success of Eurasian perch (Perca fluviatilis) and ruffe 
(Gymnocephalus cernuus). International Review of Hydrobiology 89, 229-237.

Eckmann R. \& Rősch R. (1998) Lake Constance fisheries and fish ecology. Archiv für Hydrobiologie, Special Issues Advances in Limnology 53, 285-301.

Fullerton A.H., Lamberti G.A., Lodge D.M. \& Berg M.B. (1998) Prey preferences of Eurasian ruffe and yellow perch: Comparison of laboratory results with composition of Great Lakes benthos. Journal of Great Lakes Research 24, 319-328.

Fullerton A.H., Lamberti G.A., Lodge D.M. \& Goetz F.W. (2000) Potential for resource competition between Eurasian ruffe and yellow perch: Growth and RNA responses in laboratory experiments. Transaction of American Fisheries Society 129, 1331-1339.

Gerlach G., Schardt U., Eckmann R. \& Meyer A. (2001) Kin structured subpopulations in Eurasian perch (Perca fluviatilis L.). Heredity 86, 213-221.

Gerster S., Staub E. \& Krämer A. (1995) Bewirtschaftung des Barsches im Bodensee-Obersee. BAFU, Bern (CH), Mitteilungen zur Fischerei 54, $147+$ 43pp. (Download PDF available at: http://www.umwelt-schweiz.ch/buwal/shop/ files/pdf/phpdWYdzk.pdf. Code: MFI-54-D). (in German).

Haakh T. (1929) Studien über Alter und Wachstum der Bodenseefische. Archiv für Hydrobiologie 20, 214-295 (in German).

Hartman W.L. (1972) Lake Erie: effects of exploitation, environmental changes and new species on the fishery resources. Journal of the Fisheries Research Board of Canada 29, 899-912.

Hartmann J. (1975) Der Barsch (Perca fluviatilis) im eutrophierten Bodensee. Archiv für Hydrobiologie 76, 269 286 (in German).

Hartmann J. (1977) Fischereiliche Veränderungen in kulturbedingt eutrophierenden Seen. Schweizerische Zeitschrift für Hydrologie 39, 243-254 (in German).

Hartmann J. \& Nümann W. (1977) Percids of Lake Constance, a lake undergoing eutrophication. Journal of the Fisheries Research Board of Canada 34, 1670-1677.

IGKB (1998) Submerse Makrophyten der Litoralzone des Bodensees 1993 im Vergleich mit 1978 und 1967. Berichte der internationalen Gewässerschutzkommission für den Bodensee 46, 171pp (ISSN 1011-1263) (in German).

IGKB (2004) Limnologischer Zustand des Bodensees. Jahresberichte der internationalen Gewässerschutzkommisson für den Bodensee 31, 75pp (ISSN 1011-1271) (in German).

Jeppesen E., Sondergaard M., Jensen J.P., Havens K.E., Anneville O., Carvalho L., Coveney M.F., Deneke R., Dokulil M.T., Foy B., Gerdeaux D., Hampton S.E., Hilt S., Kangur K., Köhler J., Lammens E.H.H.R., Lauridsen T.L., Manca M., Miracle M.R., Moss B., Nöges P., Persson G., Phillips G., Portielje R., Romo S., Schelske C., Straile D., Tatrai I., Willén E. \& Winder M. (2005a) Lake responses to reduced nutrient loading - an analysis of contemporary long-term data from 35 case studies. Freshwater Biology 50, 1747-1771.

Jeppesen E., Jensen J.P., Sondergaard M. \& Lauridsen T.L. (2005b) Response of fish and plankton to nutrient loading reduction in eight shallow Danish lakes with special emphasis on seasonal dynamics. Freshwater Biology 50, 16161627.

Kinzler W. \& Maier G. (2003) Asymmetry in mutual predation: possible reason for the replacement of native gammarids by invasives. Archiv für Hydrobiologie 157, 473-481.

Klunzinger B. (1892) Bodenseefische, deren Pflege und Fang. Stuttgart: Enke Verlag, 232pp. (in German).

Krämer A. \& Baroffio C. (1988) Nahrungswahl und Kannibalismus beim Barsch (Perca fluviatilis) des BodenseeObersees. Schweizerische Fischereiwissenschaft 5, 3-4 (in German).

LfU (Landesanstalt für Umweltschutz Baden-Württemberg) (2005) Wirbellose Neozoen im Bodensee. Neu eingeschleppte invasive Benthos-Arten. Monitoringprogramm Bodenseeufer 2004, 46pp (Download: http://www2.lfu.baden-wuerttemberg.de/lfu/abt4/isf/) (in German).

Leach J.J., Johnson M.G., Kelso J.R.M., Hartmann J., Nümann W. \& Entz B. (1977) Responses of percid fishes and their habitats to eutrophication. Journal of the Fisheries Research Board of Canada 34, 1964-1971.

Mills E.L., Casselman J.M., Dermott R., Fitzsimons J.D., Gal G., Holeck K.T., Hoyle J.A., Johannsson O.E., Lantry B.F., Makarewicz J.C., Millard E.S., Munawar I.F., Munawar M., O'Gorman R., Owens R.W., Rudstam L.G., Schaner T. \& Stewart T.J. (2003) Lake Ontario: food web dynamics in a changing ecosystem (1970-2000). Canadian Journal of Fisheries and Aquatic Sciences 60, 471-490.

Müller R. \& Bia M.M. (1998) Adaptive management of whitefish stocks in lakes undergoing re-oligotrophication: the Lake Lucerne example. Archiv für Hydrobiologie, Special Issues Advances in Limnology 50, 391-399.

Nümann W. (1939) Untersuchungen über die Biologie einiger Bodenseefische in der Uferregion und den Randgebieten des freien Sees. Zeitschrift für Fischerei 37, 637-688 (in German).

Nümann W. (1972) The Bodensee: effects of exploitation and eutrophication on the salmonid community. Journal of the Fisheries Research Board of Canada 29, 833-847.

Özcelik, 1978.Özcelik A. (1978) Untersuchungen über fischparasitäre Helminthen im Bodensee, $\mathrm{PhD}$ thesis. Germany: University Gießen, 91pp. (in German).

Persson L., Diehl S., Johansson L., Andersson G. \& Hamrin S.F. (1991) Shifts in fish communities along the productivity gradient of temperate lakes - patterns and the importance of size-structured interactions. Journal of Fish Biology 38, 281-293. 
Reyjol Y., Fischer P., Lek S., Rösch R. \& Eckmann R. (2005) Studying the spatio-temporal variation of the littoral fish community of Lake Constance (Germany), using Self-Organizing mapping. Canadian Journal of Fisheries and Aquatic Sciences 61, 2294-2302.

Rösch R. \& Schmid W. (1996) Ruffe (Gymnocephalus cernuus L.), newly introduced into Lake Constance: preliminary data on population biology and possible effects on whitefish (Coregonus lavaretus L.). Annales Zoologici Fennici 33, 467-471.

Roth H. \& Geiger W. (1972) Brienzersee, Thunersee, and Bielersee: effects of exploitation and eutrophication on the salmonid community. Journal of the Fisheries Research Board of Canada 29, 755-764.

Savino J.F. \& Kolar C.S. (1996) Competition between nonindigenous ruffe and native yellow perch in laboratory studies. Transactions of American Fisheries Society 125, 562-571.

Schleuter D. \& Eckmann R. (2005) Competition between perch (Perca fluviatilis) and ruffe (Gymnocephalus cernuus): the advantage of turning night into day. Freshwater Biology 51, 287-297.

Wang N. \& Eckmann R. (1994) Distribution of perch (Perca fluviatilis L.) during their first year of life in Lake Constance. Hydrobiologia 277, 135-143.

Zick D., Gassner H., Filzmoser P., Wanzenböck J., Pamminger-Lahnsteiner B. \& Tischler G. (2006) Changes in the fish species composition of all Austrian lakes $>50$ ha during the last 150 years. Fisheries Management and Ecology 13, 103-111. 